\title{
This spud's for you: a two-month, tuber-only diet
}

Published at www.cmaj.ca on Oct. 29

$\mathrm{T}$ he potato is a versatile vegetable. You can boil it, broil it, fry it, roast it, bake it and grill it. You can dice it and have it with eggs for breakfast, slice it and have it with a burger for lunch, and mash it and have it with a steak for dinner. And if you are Chris Voigt, you have it all these ways and more - every meal, every day for two months.

On Oct. 1, Voigt, the executive director of the Washington State Potato Commission, began a 60-day potatoonly diet, which he is documenting on his website (www.20potatoesaday .com). His plan is to eat 20 potatoes a day - no sour cream, no gravy, no cheese, just potatoes and a few seasonings. The purpose of his all-spud diet is twofold: to promote the nutritional value of potatoes and to demonstrate to the government that some of its policies restricting access to potatoes for school children or low-income families are unfounded.

Voigt is now more than a third of the way to meeting his goal and says his health is fine. "I'm doing great. I'm three weeks in and have lots of energy and there are no side effects. The only thing I'm struggling with is weight loss, because I'm not getting enough calories."

Because potatoes are filling, Voigt is struggling to eat 20 of them a day. Three weeks in, he has lost 12 pounds, dropping from his original weight of 197 pounds to 185 pounds. Still, as Voigt notes on his website, he is getting plenty of nutrients. Potatoes are rich in vitamin $\mathrm{C}$, potassium, dietary fibre, magnesium and vitamin $\mathrm{B}_{6}$, among other nutrients. And though few people realize it, notes Voigt, potatoes also contain protein. $\mathrm{He}$ acknowledges, though, that his twomonth diet is hardly balanced.

"One food product is obviously not enough," he says.

His goal is not to promote a oneproduct diet, but rather to make a point.

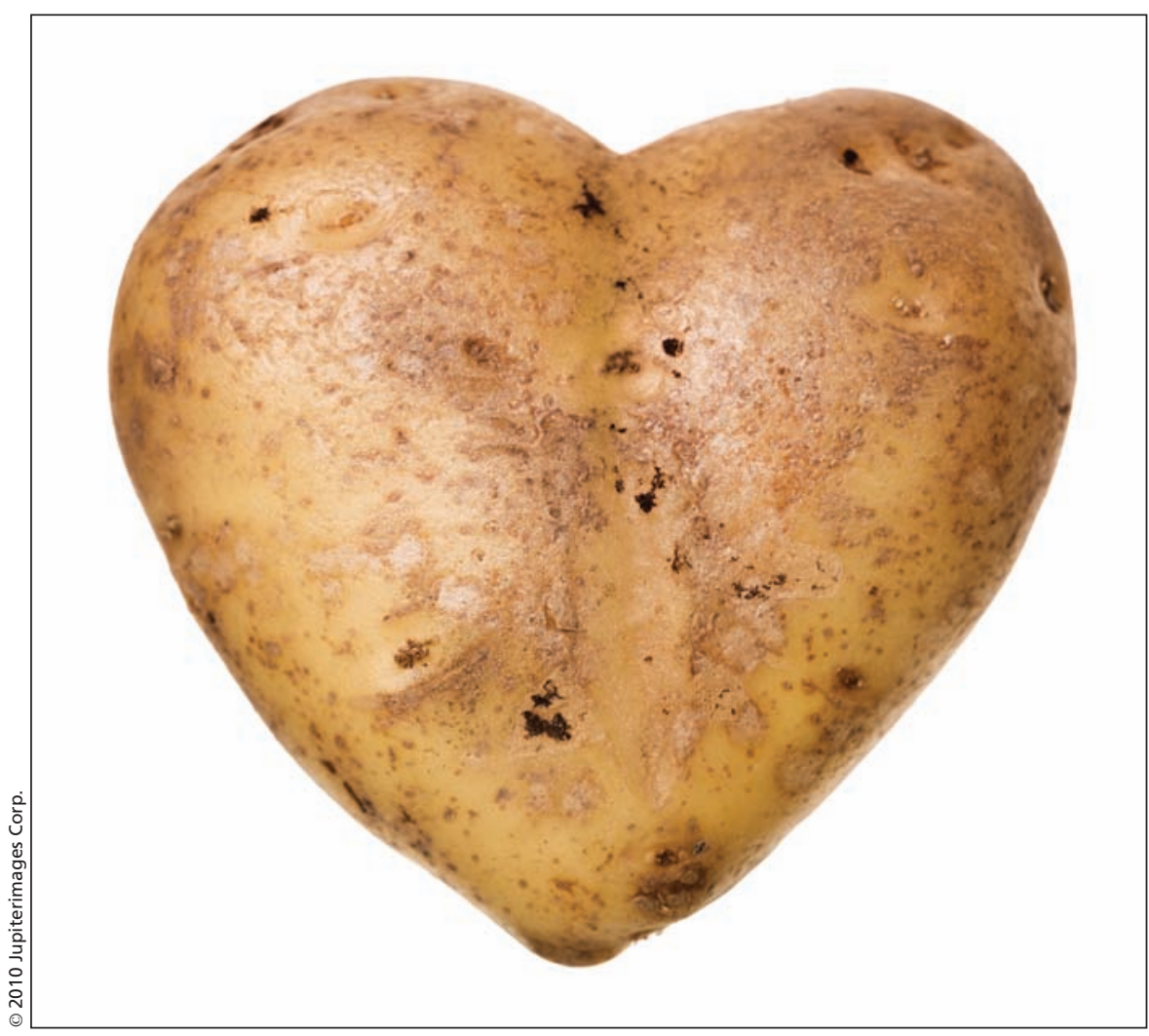

The plain, old ordinary tater is cardiovascular-friendly? Scientists are exploring how bioactive compounds in different types of potatoes can be extracted and used to help fight stroke, diabetes, heart disease, neurodegenerative diseases and other health problems.

In recent years, the reputation of the potato has been unfairly maligned by people promoting low-carbohydrate diets, says Voigt. And many of the calories in high-calorie potato dishes come from toppings or oil, not the tuber itself. But the body needs carbohydrates, notes Voigt, and there are many healthy ways of preparing potatoes.

The United States government, however, doesn't appear to see the potato in such a positive light. It has been considering plans to restrict the number of potatoes that surface in federal child nutrition programs. The Institute of Medicine has recommended that potatoes be limited in the federal school lunch program and banned from the Women, Infants and Children program, a national supplemental food program.
"I'm hoping to use my diet as a tool to convince the federal government to change some of its policies," says Voigt. "I want the government to know that potatoes are not the scourge of the earth, and this is my way of saying, 'I'll prove it to you.' "'

According to Jennifer Sygo, a registered dietitian and director of nutrition for Cleveland Clinic Canada in Toronto, Ontario, the potato is indeed sadly misunderstood. "I think that the potato has, unfairly, gained a bad reputation," she says. "In the movement away from carbohydrates, the potato has been an easy target."

Though she would never, of course, recommend that someone eat only potatoes, Sygo says Voigt's point is valid. "Is it a healthy balanced diet? Of 
course not - not by a long shot. But he is right that you can meet a lot of your nutritional needs if you eat enough potatoes in a day. You could do worse as far as a single food goes."

A potato contains $120-170$ calories, Sygo notes, which is on par with a slice and a half of bread. It is rich in vitamin C, so at least Voigt doesn't have to worry about scurvy. It contains magnesium and potassium, which are good for controlling blood pressure. A potato has 2-4 grams of protein, so an adult male would have to eat quite a few to meet his daily requirement (about 56 grams on average). Potatoes don't have vitamin $\mathrm{A}$ or vitamin $\mathrm{E}$, however, and a person who consumes only spuds would quickly become deficient in these nutrients, which aid eyesight, sustain the immune system, support bone growth and protect against cell damage.

But as part of a balanced diet, potatoes come highly recommended by Sygo. "If you don't boil the pants off them and you don't take off the skin, it can be part of a healthy diet. As soon as you're talking about sour cream and bacon bits and grated cheese, that's a totally different animal. It's all about the portions and the preparation and the toppings."

In addition to going easy on the sour cream, eating a wider variety of potatoes can also have health benefits. In North America, people tend to eat only white or yellow potatoes. Europeans, by contrast, eat many different types of potatoes - red, blue and purple, to name a few. They also eat twice as many potatoes as North Americans, says Bob Chapman, director of research for the National Research Council Canada Institute for Nutrisciences and Health in Charlottetown, Prince Edward Island.

Chapman is part of the BioPotato Network, a Canadian program with scientists from government, industry and academia that is exploring how bioactive compounds in different types of potatoes can be extracted and used to help fight stroke, diabetes, heart disease, neurodegenerative diseases and other health problems, such as allergies. The network is divided into four streams: bioactives, functional food and nutraceuticals; low glycemic index and high fibre functional food; new potato starch for functional food, pharmaceutical and bioplastic uses; and botanical insecticides and biopesticides for insect control. One of its goals is to diversify Canada's potato industry, which includes getting purple taters on Canadian dinner tables.

"There are not a large amount of coloured potatoes sold in North America. The BioPotato Network wants to change that," says Chapman. "We are looking at which ones have better health benefits and which ones might be liked more by consumers."

As for Voigt, he has of late been wishing he set a goal of 30 days instead of 60 . Though he feels fine, and though he still loves potatoes, he is getting tired of seeing only spuds on his plate. "About $60 \%$ of the time, it's OK. Then about $30 \%$ of the time, it's a struggle. I think, 'Boy, that taco that guy is eating sure looks good.' And about $10 \%$ of the time, I feel like throwing in the towel. I really, really want to eat something else." — Roger Collier, CMAJ

DOI:10.1503/cmaj.109-3719 